\title{
Ações em saúde vocal: proposta de melhoria do perfil vocal de professores $* * * * * *$
}

\author{
Kelly Cristina Alves Silverio* \\ Claudia Giglio de Oliveira Gonçalves*** \\ Regina Zanella Penteado*** \\ Tais Pichirilli Guilherme Vieira**** \\ Aline Libardi***** \\ Daniele Rossi*****
}

\section{Actions in vocal health: a proposal for improving the vocal profile of teachers}

*Fonoaudióloga. Doutora em Ciências pela Faculdade de Odontologia de Piracicaba - Universidade de Campinas. Docente do Programa de Mestrado em Distúrbios da Comunicação Humana da Universidade Tuiuti do Paraná. Endereço para correspondência: Rua Margarida Dallarmi, 75 - casa 3 Curitiba - PR - CEP 82015-690 (kelly.silverio@utp.br)

**Fonoaudióloga. Doutora em Saúde Coletiva pela Universidade de Campinas. Docente do Programa de Mestrado em Distúrbios da Comunicação Humana da Universidade Tuiuti do Paraná

***Fonoaudióloga. Doutora em Saúde Pública pela Faculdade de Saúde Pública da Universidade de São Paulo. Docente do Curso de Fonoaudiologia da Universidade Metodista de Piracicaba.

****Fonoaudióloga. Especializanda em Cabeça e Pescoço na Santa Casa de Misericórdia de São Paulo.

******Fonoaudióloga pela Universidade Metodista de Piracicaba.

*******Trabalho Realizado na Universidade Metodista de Piracicaba. Agências de Financiamento: Fundo de Apoio à Pesquisa (FAP) pela Universidade Metodista de Piracicaba.

Artigo Original de Pesquisa

Artigo Submetido a Avaliação por Pares

Conflito de Interesse: não

Recebido em 05.11.2007.

Revisado em 13.03.2008; 07.05.2008; 29.07.2008.

Aceito para Publicação em 29.07.2008.

\section{Abstract}

Background: several authors have pointed to the urgent need of researches and actions involving teachers, in the school environment, that have a preventive and vocal health promotion character with the purpose of improving work conditions. Aim: to analyze the vocal complaints, laryngeal symptoms, vocal habits and vocal profile of teachers of a public school before and after their participation in voice workshops. Method: the study was divided in different steps: 1st step - closed interview, larynx and perceptive-auditory assessment in which 42 teachers were evaluated; 2 nd step - voice workshops; 3 rd step - perceptive-auditory reassessment in which 13 teachers were evaluated. Results: $73 \%$ of the subjects presented vocal complaints; $57.14 \%$ presented mild to moderate hoarseness, $78.57 \%$ presented breathiness and $52.38 \%$ vocal tension. Evaluation of the larynx indicated that $75.86 \%$ of the subjects presented glottal gaps and $34.48 \%$ mucous thickening. After the voice workshops a significant difference was observed in the level of vocal tension, both in the analysis of the /e/ vowel and in the analysis of Spontaneous Speech ( $p=0.0277$ for $p>0.05$ for both). Improvement was observed in vocal care and in the understanding of intervening and determinant factors for vocal alterations, which are present in the teaching environment. Conclusion: health actions, such as voice workshops, are important to trigger changes in the work environment as well as in the health of teachers.

Key Words: Voice; Teacher; Occupational Health; Health Promotion.

\section{Resumo}

Tema: vários autores têm apontado a urgência de se intensificar pesquisas e ações voltadas ao professor, na escola, de caráter preventivo e de promoção de saúde vocal, que se volta para a melhoria das condições de trabalho e do ambiente no qual ocorre a docência. Assim sendo, o objetivo deste estudo foi: analisar as queixas, os sintomas laríngeos, hábitos relacionados ao desempenho vocal e o tipo de voz de professores de uma escola da rede pública de ensino antes e após a participação em grupos de vivência de voz. Método: o estudo foi dividido em etapas com professores de uma escola pública: $1^{\text {a }}$ Etapa: entrevista, avaliação laringológica e perceptivo-auditiva da qual participaram 42 professores; $2^{\mathrm{a}}$ Etapa: grupos de vivência de voz e $3^{\text {a }}$ Etapa: reavaliação perceptivo-auditiva - das quais participaram 13 professores. Resultados: $73 \%$ dos sujeitos apresentaram queixas vocais; $57,14 \%$ apresentaram rouquidão de grau leve e moderado, $78,57 \%$ apresentaram soprosidade e 52,38\% apresentaram tensão na voz. Ao exame laringológico, $75,86 \%$ apresentaram fendas glóticas e 34,48\% espessamento mucoso. Após a vivência de voz houve diferença significativa no grau de tensão, tanto na análise da vogal /e/ como na análise da fala espontânea ( $\mathrm{p}=0,0277$ para $\mathrm{p}>0,05$ para ambas). Houve melhora dos cuidados com a voz e a compreensão dos fatores intervenientes e determinantes das alterações vocais, presentes nas condições e organização do trabalho docente. Conclusão: ações educativas processuais, como os grupos de vivência de voz, se caracterizam como importantes espaços de reflexão e de mudança das relações entre trabalho e saúde do professor.

Palavras-Chave: Voz; Docente; Saúde Ocupacional; Promoção da Saúde.

Referenciar este material como:

Silverio KCA, Gonçalves CGO, Penteado RZ, Vieira TPG, Libardi A, Rossi D. Actions in vocal health: a proposal for improving the vocal profile of teachers (original $\sum 3$ title: Ações em saúde vocal: proposta de melhoria do perfil vocal de professores). Pró-Fono Revista de Atualização Científica. 2008 jul-set;20(3):177-82. 


\section{Introduction}

Work relations and health have been historically determined based in specific social, cultural, economic and productive relations that are oriented by health policies that have underlying concepts and assumptions. This way the means of understanding and evaluating citizens, the healthillness process and health itself vary in different times and places.

The working class studied here is the one of teachers. They have been subjects of studies due to vocal disorders that hinder their activity because it depends on hearing, voice, speech and language as didactic resources and to the teacher-student interaction (1).

Dysphonia have been considered for some time a work-related condition, involving clinical or pathological predispositions as well as recognized concepts and evidences, the environmental hazards and working situations (1-4).

Several authors have pointed out to the urgency to intensify researches and actions focused on the teachers at school. They should have a preventive character, promoting vocal health based on improvements of working and environmental conditions (5-10).

This way, the aim of this study was to analyze the complaints, the laryngeal symptoms, habits related to vocal performance and voice quality of teachers of the public educational system prior and after the participation in voice experience groups.

\section{Method}

Subjects were 42 teachers of a public first grade school of Piracicaba (SP), of the female gender, ages 25 to 52 years. All of them signed the consent form approved by the institution's research commission.

The study was conducted in three steps. On the first step the teachers answered to a questionnaire about vocal complaints, laryngeal symptoms, vocal habits and provided a vocal sample to percipient-auditory analysis.

The voice recorded consisted on the emission of the sustained vowel /?/, isolated, in habitual frequency and intensity and spontaneous speech. A digital recorder Mini-Disc (Sony-MDS-520) was used with single-directional stereo microphone (lesson-SM58), placed at $15 \mathrm{~cm}$ of the speaker's mouth and mini-discs (Sony) used on a silent room at the school. The percipient-auditory analysis was performed by three examiners, voice specialists, based on the GRBASI scale (11) and by consensus.
The laryngological evaluation consisted on telelaringostroboscopy performed by an otorhinolaringologist.

On the second step the results of the first step were presented to the teachers in order to make them aware of their vocal problems and to motivate them to participate on the vocal experience group. Twelve 1-hour meetings were conducted, focusing the issues: vocal psychodynamics and selfpercipient vocal analysis, notions about larynx and voice production anatomy and physiology, vocal health and vocal habits, vocal warming and cooling exercises, environmental and working conditions and working organization. The meetings were videotaped in order to allow the analysis and transcription of the discussions.

On the third step the vocal the vocal sampling was repeated in order to verify possible changes. The laryngological evaluation wasn't repeated because the teachers refused to repeat the exam, claiming it is too uncomfortable.

After the percipient-auditory analysis of the /?/ vowel and of the spontaneous speech the average and standard deviation of the values of groups prior- and post-voice experiences and the ShapiroWilk normality test with software JMP , 3.1.6.2 version was used to assess data distribution.. Data were analyzed by the Wilcoxon hypothesis test with the software Statgraphics Plus version 1.4. The critical level for analysis was fixed on $5 \%(\mathrm{p}<0.05)$.

\section{Results}

First step - interviews

In what refers to vocal complaints, 31 teachers $(73.8 \%)$ report hoarseness, weak voice, strident voice, voice loss, vocal tiredness, throat ache and voice failures.

The most referred laryngeal symptoms were: tiredness while speaking (13 teachers $-30.95 \%)$, throat irritation or harshness 20 teachers $-47.61 \%$ ), feelings of dry/harsh throat (26 teachers - 61.90\%), breathlessness while speaking (12 teachers $28.57 \%$ ), cough (12 teachers $-28.57 \%$ ) and throat itch (18 teachers $-42.85 \%)$. It is important to point out that 34 teachers $(87 \%)$ reported two or more symptoms.

In relation to the habits the most part of the subjects $(26-61.90 \%)$ reported drinking water during classes despite ignoring the importance of this habit to vocal health. Besides, 23 teachers $(54.76 \%)$ drink coffee daily between classes and on other times of day, 5 (11.9\%) drink alcohol and 3 
$(7.14 \%)$ are smokers. Only 3 teachers $(7.14 \%)$ did not report habits that are considered bad for the health. The most frequently reported vocal habits were: screaming (24 teachers - 57.14\%) and speaking with augmented voice intensity (24 teachers $57.14 \%$ ). Most of the subjects (32 teachers -57.14 ) reported the association of these habits that are considered risk factors to dysphonia.

Percipient auditory analysis

Of the 42 teachers that were analyzed 39 $(92.85 \%)$ presented some degree $(\mathrm{G})$ of dysphonia on the production of the /?/ vowel. The most disturbed parameters were hoarseness (R), breathiness (B), stress (S) and instability (I). The parameter asthenia (A) was not observed on their vocal quality.

In spontaneous speech, $36(86 \%)$ teachers presented dysphonia $(\mathrm{G})$, with the most frequent parameters being: hoarseness (R), breathiness (B) and stress (S) on voice. Instability (I) and asthenia (A) were not observed on any of the teachers (Figure 2).

Laryngological assessment

Only $29(69 \%)$ teachers went through laryngological assessment, the others denied, claiming to be afraid of the exam. From them, 26 (90\%) received a diagnosis of disorder: gap of the glottis (22 teachers - 75.86\%), mucous thickening (10 teachers - 34.48), edema and hyperemia (7 teachers), supra-glottic constriction (5 teachers $17.24 \%$ ), cists (4 teachers - $13.79 \%$ ), Reinke edema (1 teacher $-3.44 \%$ ), vascular-malformation ( 1 teacher $-3.44 \%$ ) and vocal cleft ( 1 teacher $-3.44 \%)$. It is important to point out that that $18(69.23)$ teachers presented diagnostics of associated voice disorders.

Second step - voice experience group

Thirteen teachers participated effectively of the voice experience groups.

Aspects of the vocal psychodynamics and vocal abuse in classroom were addressed. Despite displaying difficulties in perceiving their own voices the teachers identified hoarseness, sensation of harsh throat, improvement of voice during vacations and deterioration during classes with consequences on the impact of their voices on the listeners: lack of confidence sensation and low vocal power, implying weakness. They justified the vocal abuses on classrooms due to the vocal competition with the students.

Vocal warming exercises were conducted before the classes and cooling exercises were made after the classes, reestablishing the habitual voice intensity, more appropriate to the environment, preventing vocal abuses and latter feelings of tiredness. Cervical relaxation exercises were proposed along with vocal warming (chewed $/ \mathrm{m} /$, voiced fricative phonemes and vibrating ascendant and descendant technique). The vocal cooling was done with the same exercises, but with descendant scale, in order to promote the return to the normal intensity and frequency of the regular speech.

The body relaxation was also conducted aiming to work body self perception. Teachers reported feelings of "mental relaxation" and this practice is necessary to the procedure reducing bodily and emotional overload.

During the discussion of possible environmental and working organization changes it was reported that the school knew about the causes of the problems and their relation to the school environment, but still can not envision real and viable possibilities to modify the situation. During the meetings, however, there were other progresses in this aspect as the changes in the classroom aiming to minimize the students' noise due to lack of interest on the contents and troubles controlling the group. Teachers proposed alternative solutions as: placing the students in a circle in the classroom allowing all of them to look at each other and to participate more avoiding dispersion of attention and vocal abuse by the teacher; allow the final 20 minutes of the classes to discuss students' life issues allowing affective bonds, increasing their interest once they receive interest.

Third step: percipient-auditory analysis after the voice experience

Prior and after the participation on the voice experience there was no difference on the parameters: Dysphonia Degree, Hoarseness, Breathiness, Asthenia and Instability either in the / $\varepsilon /$ vowel or in spontaneous speech. However, there was significant difference on the Stress Degree in the /ع/ vowel and in spontaneous speech (Table 1). 
FIGURE 1. Distribution of the teachers according to the parameters of GRBASI11 scale during the percipient-auditory analysis of the / $\varepsilon /$ vowel, prior to the voice-experience group $(\mathrm{N}=42)$.

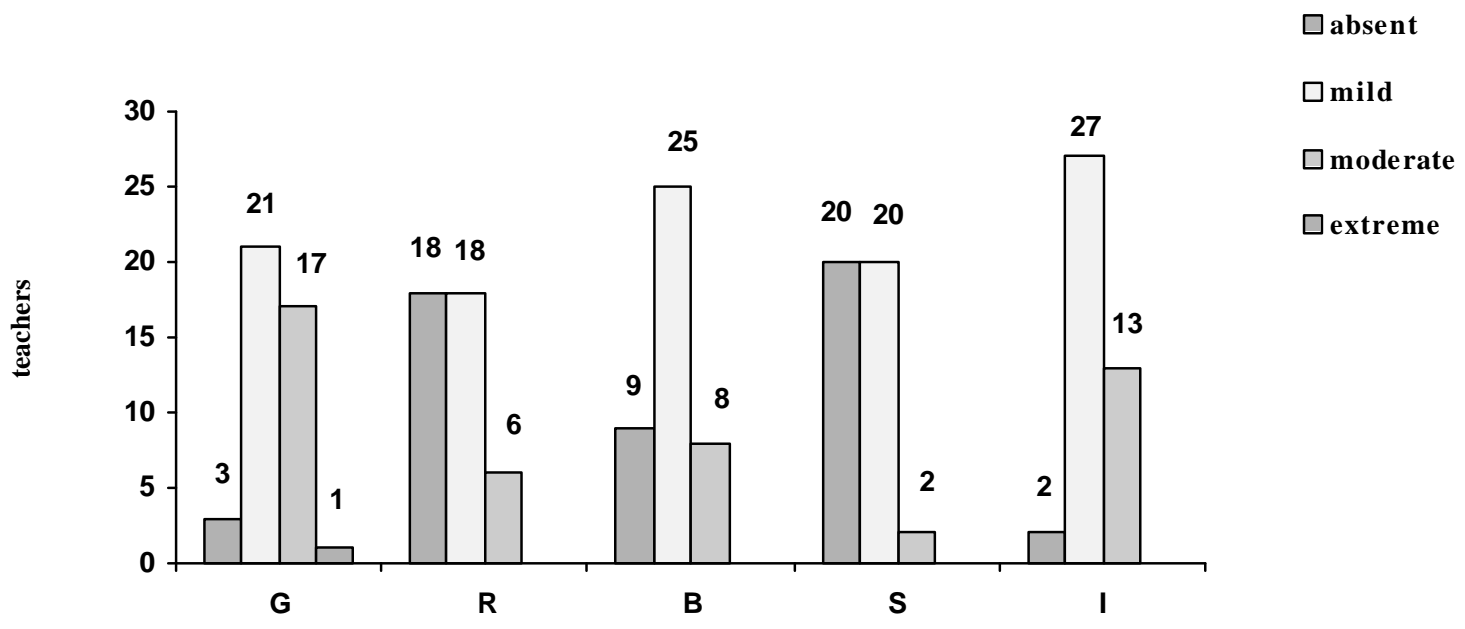

FIGURE 2. Distribution of teachers according to the parameters of the GRBASI11 scale during the percipient-auditory analysis of spontaneous speech. $(\mathrm{N}=42)$.

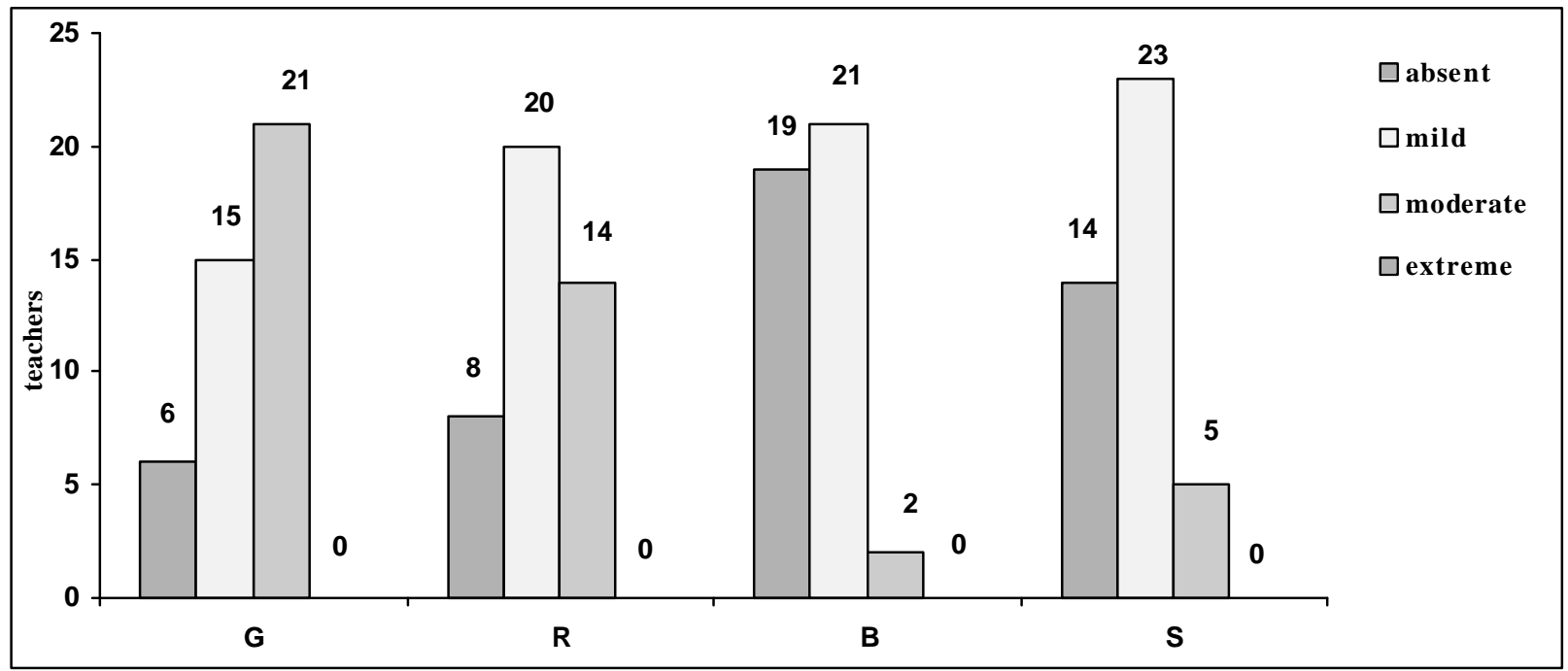

TABLE 1. Average standard deviation (sd) and P-value attributed on the percipient analysis of the / $/$ / vowel and spontaneous speech, about the parameters of the GRBASI(11) scale of the subjects evaluated prior and after the voice experience groups $(\mathrm{N}=13)$.

Percipient-auditory analisis

/e/ Vowel Spontaneous speech

\begin{tabular}{lcccccc}
\hline Parameters & $\begin{array}{c}\text { Prior-experiences } \\
\text { Average } \pm \mathrm{sd}\end{array}$ & $\begin{array}{c}\text { Post- experiences } \\
\text { Average } \pm \text { sd }\end{array}$ & $\begin{array}{c}\text { P-value } \\
\text { A }\end{array}$ & $\begin{array}{c}\text { Prior-experiences } \\
\text { Average } \pm \mathrm{sd}\end{array}$ & $\begin{array}{c}\text { Post experiences } \\
\text { Average } \pm \text { sd }\end{array}$ & P-value \\
\hline G - disphonia degree & $1 . .38 \pm 0 . .51$ & $1.15 \pm 0.38$ & 0.2249 & $1.23 \pm 0.44$ & $0.85 \pm 0.69$ & 0.1158 \\
$\mathrm{R}$ - hoarseness degree & $0.69 \pm 0.75$ & $0.77 \pm 0.73$ & 0.7315 & $1.08 \pm 0.64$ & $0.69 \pm 0.63$ & 0.1158 \\
$\mathrm{~B}$ - breathiness degree & $0.77 \pm 0.73$ & $0.62 \pm 0.51$ & 0.5001 & $0.23 \pm 0.44$ & $0.23 \pm 0.44$ & 1 \\
A - asthenia degree & 0 & 0 & 0 & 0 & 0 & 0 \\
S - stress degree & $0.85 \pm 0.55$ & $0.38 \pm 0.51$ & $* 0.0277$ & $0.69 \pm 0.48$ & $0.23 \pm 0.44$ & $* 0.0277$ \\
I - instability degree & $1.08 \pm 0.64$ & $1.31 \pm 0 . .58$ & 0.2249 & 0 & $0 \pm 0$ & 0 \\
\hline
\end{tabular}

$* p>0.05$ 


\section{Discussion}

In what refers to the vocal complaints presented by the teachers the results of this study agree with other authors that found complaints of hoarseness, throat irritation or harshness, loss of voice and muscular tension on the neck region during phonation (12-14). Some studies state that these complaints are predisposing factors for occupational dysphonia which results from the inadequate use of voice by the teachers $(3,4,15)$.

The laryngeal symptoms and sensations reported indicate breath-voice-articulation incoordination, stress while speaking and lack of laryngeal moisturizing that may accompany vocal changes or not (16).

The lack of relations between laryngeal symptoms and vocal problems brings to evidence the absence of knowledge about vocal health and signs of dysphonia (17). These data point to the need of a prevention program that include orientation to teachers aiming to avoid laryngeal lesions that worsens the speech situation in classrooms leading to prolonged treatments and work absences. Several recent studies discussing teachers' vocal health and occupational dysphonias of this group of workers suggest prevention programs, vocal training and environmental control $(1,6,10,18)$.

The percipient-auditory analysis evidenced vocal disorder in most of the teachers both on the /ع/ vowel emission and on spontaneous speech and the most disordered parameters were hoarseness, breathiness and stress. Hoarseness appears in other studies as the most frequent vocal disorder in teachers $(1,4,10)$.

The findings of the larynx exam are consistent with the complaints, laryngeal symptoms reported and percipient-auditory analysis. All laryngeal conditions found (except the vocal cleft) are due to the vocal wrong use and abuse, as well as to the intensive use of voice, absence of basic care to keep the vocal health and therefore good communication in the classroom. This way, these findings agree with other studies about laryngeal disorders among teachers $(1,10,15)$.

In what refers to the groups of voice experience, the teachers' expectancies related to the meetings were to learn vocal exercises that could reduce the laryngeal symptoms. They reported normal voices despite complaints about tiredness and hoarseness by the end of the week, showing difficulties to perceive their own voices and how vulnerable they are to dysphonies $(1,4,14,19,20,21)$.
To approach issues about vocal psychodynamics to group was lead to think about the influences of emotion on the voice in different situations. Most of them reported speaking with high intensity at home, adding that it has a negative impact on familiar relations. This fact may be a consequence of professional stress and also of a lack of voice cooling process what makes many teachers use their voices with more intensity then necessary (21).

Another fact discussed was the occurrence of voice abuses in the classroom. The excessive number of students in each class, the lack of discipline, the un-attention, communication and relationship troubles between teachers and students were factors presented as causes of several teachers' health problems, as negative feelings, stress and depression. Besides that, increased stress while speaking, sound competition and increased voice intensity favor vocal abuses $(7,8,12,19)$. A comparative study (7) about dysphonias and risk factors in undergraduate teaching students and in experienced teachers observed that the stress, the work pressure, the class group and psycho-emotional factors had negative influence on the teachers' voices. But the students believed that environmental factors and vocal intensity were risk factors to developing dysphonia.

About possible environmental and organizational working changes the teachers' reports evidenced that they had a working overload, multiple activities and functions due to lack of planning or executive organization of school's activities and that it generated feelings of personal pressure and internal and external self demands. These factors generate tension, conflicts, frustrations, fatigue and stress that are hazardous to teacher's health and produce vocal disorders $(7,22)$.

After participating on the voice experience groups, despite the continuity of laryngeal complaints and symptoms it could be noticed that they were attenuated and there was a discrete increase on the teachers' capacity of identifying when they talk too much and to avoid inadequate vocal behaviors, minimizing uncomfortable sensations.

The improvement on the stress degree parameter after the voice experience groups, both on the $/ \varepsilon /$ vowel production and on spontaneous speech reflects changes on voice health care: more water ingestion during classes, performing voice warming exercises, vocal self-control and avoiding screaming or speaking with high intensity according to teachers' reports.

Other aspect that contributed to the decrease on vocal tension was the discussion about the work 
organization troubles that interfere with professional activity and teachers' lives. Thinking and speaking about problematic issues decrease tensions and provide opportunities of collectively seek for their solutions or attenuation.

\section{Conclusions}

The significant number of voice disorders observed in teachers shows the poor conditions of vocal health of these subjects.

\section{References}

1. Smolander S, Huttunen K. Voice problems experienced by Finnish comprehensive school teachers and realization of occupational health care. Logoped Phoniatr Vocol. 2006;1(4):166-71.

2. Kooijman PG, Thomas G, Graamans K, de Jong FI. Psychosocial impact of the teacher's voice throughout the career. J. Voice. 2007;21(3):316-24.

3. Nix J, Svec JG, Laukkanen AM, Titze IR. Protocol challenges for on-the-job voice dosimetry of teachers in the United States and Finland. J Voice. 2007;21(4):38596.

4. Hamdan AL, Sibai AM, Srour ZM, Sabra OA, Deeb RA. Voice disorders in teachers. The role of family physicians. Saudi Med J. 2007;28(3):422-8.

5. Gonçalves CGO, Penteado RZ, Silverio KCA. Fonoaudiologia e Saúde do Trabalhador: a questão da saúde vocal do professor. Saúde em Revista - Saúde do Trabalhador. 2005;7(15):46-51.

6. Kooijman PG, de Jong FI, Thomas G, Huinck W, Donders $\mathrm{R}$, Graamans $\mathrm{K}$, et al. Risk factors for voice problems in teachers. Folia Phoniatr Logop. 2006;58(3):159-74.

7. Thomas G, Kooijman PG, Cremers CW, de Jong FI. A comparative study of voice complains and risk factors for voice complaints in female student teachers and practicing teachers early in their career. Eur Arch Otorhinolaryngol. 2006;263(4):370-80.

8. Penteado RZ, Pereira IMTB. Qualidade de vida e saúde vocal de professores. Rev. Saúde Pública. 2007;41(2):23643.

9. Grillo MHMM, Penteado RZ. Impacto da voz na qualidade de vida de professore(a)s do ensino fundamental. Pró-fono Rev. Atual. Cient. 2005;17(3):321-30.

10. Tavares EL, Martins RH. Vocal evaluation in teachers with or without symptoms. J Voice. 2007;21(4):407-14.

11. Hirano M. Clinical Examination of Voice. New York: Springer-Verlag; 1981.

12. Sliwinska-Kowalska M, Niebudeck-Bogusz E, Fiszer M, Los-Spychalska T, Kotylo P, Sznurowska-Przygocka B, et al. The prevalence and risk factors for occupational voice disorders in teachers. Folia Phoniatr Logop. 2006;58(2):85101 .
The participation on the vocal experience groups reduced teachers' vocal tension and helped them to understand the causes of this tension.

The study shows the importance and the necessity of vocal health programs with the aim of preventing dysphonias and promoting teachers' vocal health directed to undergraduate teaching students and public schools' teachers. The educative actions therefore should have mobile characteristics and be based on dialogue, reflection, discussion and possibility of changes through active subjects' participation.

13. Smith E, Kirchner HL, Taylor M, Hoffman H, Lemke J. Voice Problems Among Teachers: Differences by Gender and Teaching Characteristics. Journal of Voice. 1998;12(3):328-34.

14. Fabron EMG, Sebastião LT, Omote S. Prevenção de distúrbios vocais em professores e crianças: uma proposta de intervenção junto a instituições educacionais. In: Giroto CRM, Org. Perspectivas Atuais da Fonoaudiologia na Escola. São Paulo: Plexus; 1999. p. 72-88.

15. Niebudeck-Bogusz E, Kotylo P, Sliwinska-Kowalska M. Evaluation of voice acoustic parameters related to the vocal-loading test in professionally active teachers with dysphonia. Int $\mathbf{J}$ Occup Med Environ Health. 2007;20(1):25-30.

16. Cancian P, Passos GC, Martins EC, Perez F. Projeto Saúde Vocal do Professor: estratégias de intervenção em grupo - relato de experiência. In: Ferreira, LP, Silva MAA, Orgs. Saúde Vocal: práticas fonoaudiológicas. São Paulo: Rocca; 2002. p. 191-7.

17. Behlau M, Dragone MLS, Nagano L. A voz que ensina: o professor e a comunicação oral em sala de aula. Rio de Janeiro: Revinter; 2004.

18. Ilomäki I, Mäki E, Laukkanen AM. Vocal symptoms among teachers with and without voice education. Logoped Phoniatr Vocol. 2005;30(3-4):171-4.

19. Schwarz K, Cielo C. A. A voz e as condições de trabalho de professores de cidades pequenas do Rio Grande do Sul. Revista da Sociedade Brasileira de Fonoaudiologia. 2005;10(2):83-90.

20. Chun RYS. Voz Profissional: repensando conceitos e práticas na promoção da saúde vocal. In: Ferreira, LP, Silva MAA, Orgs. Saúde Vocal: práticas fonoaudiológicas. São Paulo: Rocca; 2002. p. 19-31.

21. Simões M, Latorre MRDO. Prevalência de alteração vocal em educadoras e sua relação com a auto-percepção. Rev. saúde pública. 2006;40(6):1013-8.

22. Vaz ACN, Rodrigues MV, Carvalho LR, Trentini AL, Melissopoulos CBG, Campos, ASC, et al. Voz do Professor: prevenir é preciso. In: Ferreira, LP, Silva MAA, Orgs. Saúde Vocal: práticas fonoaudiológicas. São Paulo: Rocca; 2002. p. 199-205. 